\title{
MENINGKATKAN HASIL BELAJAR PKN MATERI MENJAGA KEUTUHAN NKRI MELALUI PENERAPAN MODEL PEMBELAJARAN KOOPERATIF TIPE NUMBER HEAD TOGETHER (NHT) PADA SISWA KELAS V SD NEGERI 1 NELOMBU
}

\author{
Nurlian $^{1)}$, Lisnawati Rusmin ${ }^{1)}$, La Ode Safiun Arihi ${ }^{1)}$ \\ ${ }^{1)}$ Jurusan Pendidikan Guru Sekolah Dasar \\ FKIP Universitas Halu Oleo \\ email: nurlian.pji@gmail.com, lisnawatirusmin0@gmail.com,
}

\begin{abstract}
Abstrak: Rumusan masalah dalam penelitian ini adalah apakah aktivitas mengajar guru, aktivitas belajar siswa dan hasil belajar siswa pada materi Menjaga Keutuhan NKRI dapat ditingkatkan melalui penerapan Model Pembelajaran Kooperatif Tipe NHT di Kelas V SDN 1 Nelombu? Tujuan penelitian ini adalah untuk meningkatkan aktivitas mengajar guru, aktivitas belajar siswa dan hasil belajar siswa pada materi Menjaga Keutuhan NKRI melalui penerapan Model Pembelajaran Kooperatif Tipe NHT di Kelas V SDN 1 Nelombu Kabupaten Kolaka. Jenis penelitian ini adalah penelitian tindakan kelas, terdiri dari dua siklus yang setiap siklusnya terdiri dari dua kali pertemuan. Prosedur penelitian ini meliputi: perencanaan, pelaksanaan tindakan, observasi dan evaluasi, dan refleksi. Berdasarkan hasil analisis dan pembahasan, menunjukkan bahwa pada siklus I 11 siswa tuntas belajar dengan persentase sebasar 68,8\% dan rata-rata 67,14 sedangkan pada siklus II 15 siswa tuntas belajar dengan persentase sebesar 93,8\% dan rata-rata 77,86. Pada siklus I persentase aktivitas mengajar guru pertemuan pertama adalah $73,33 \%$ dan pertemuan kedua $86,67 \%$ sedangkan pada siklus II persentase aktivitas mengajar guru pertemuan pertama sebesar 93,33\% dan pertemuan kedua sebesar $100 \%$. Pada siklus I persentase aktivitas belajar siswa pertemuan pertama adalah 73,33\% dan pertemuan kedua $86,67 \%$ sedangkan pada siklus II pertemuan pertama sebesar $93,33 \%$ dan $100 \%$ pada pertemuan kedua. Disimpulkan bahwa melalui model pembelajaran kooperatif tipe NHT dapat meningkatkan hasil belajar PKn siswa pada materi pokok Menjaga keutuhan NKRI di kelas V SDN 1 Nelombu Kabupaten Kolaka.
\end{abstract}

Kata kunci: Model pembelajaran; Number Head Together; hasil belajar PKn

\section{IMPROVING THE RESULTS OF PKN LEARNING MATERIALS TO KEEP THE INTEGRITY OF THE REPUBLIC OF INDONESIA THROUGH THE IMPLEMENTATION OF THE MODEL COOPERATIVE LEARNING NUMBER HEAD TOGETHER (NHT) IN CLASS V STUDENTS OF SDN 1 NELOMBU}

\begin{abstract}
The formulation of the problem in this study is whether the teacher teaching activities, student learning activities and student learning outcomes on the material Maintaining the Unity of the Republic of Indonesia can be improved through the application of the NHT Type Cooperative Learning Model in Class V SDN 1 Nelombu? The purpose of this study is to improve teacher teaching activities, student learning activities and student learning outcomes in the material Maintaining the Unity of the Republic of Indonesia through the implementation of the NHT Type Cooperative Learning Model in Class V SDN 1 Nelombu, Kolaka Regency. This type of research is classroom action research, consisting of two cycles, each cycle consisting of two meetings. The procedures of this research include: planning, implementing actions, observing and evaluating, and reflecting. Based on the results of the analysis and discussion, it shows that in the first cycle 11 students completed learning with a percentage of $68.8 \%$ and an average of 67.14 while in the second cycle 15 students completed learning with a percentage of $93.8 \%$ and an average of $77,86$. In the first cycle the percentage of teaching activities of the first meeting teachers was $73.33 \%$ and the second meeting was $86.67 \%$ while in the second cycle the percentage of teaching activities of the first meeting teachers was $93.33 \%$ and the second meeting was $100 \%$. In the first cycle the percentage of student learning activities in the first meeting was $73.33 \%$ and the second meeting was $86.67 \%$ while in the second cycle the first meeting was $93.33 \%$ and $100 \%$ in the second meeting. It was concluded that through the NHT type cooperative learning model can improve student learning outcomes PKn on the subject matter Maintain the integrity of the Unitary Republic of Indonesia in class V SDN 1 Nelombu, Kolaka Regency.
\end{abstract}

Keywords: Learning model, Number Head Together, Learning outcomes, 


\section{Pendahuluan}

Pendidikan Kewarganegaraan sebagai salah satu cabang ilmu pengetahuan memegang peranan penting dalam pengembangan ilmu pengetahuan dan teknologi. PKn sebagai bagian dari pendidikan dipilih sebagai sarana bagi siswa agar mampu berpikir logis, etis dan sistematis, hal ini sesuai dengan fungsi pelajaran PKn yang dirumuskan dalam kurikulum, yaitu sebagai wahana untuk mengembangkan penalaran yang dapat menjelaskan permasalahan dalam kehidupan seharihari. Oleh karena itu masalah kualitas pengajaran PKn memerlukan perhatian yang serius dari pihak-pihak yang terkait, khususnya para guru PKn yang mengelola pembelajaran secara langsung didalam kelas.

Soemantri (2007:25) mengemukakan bahwa Pendidikan Kewarganegaraan merupakan mata pelajaran sosial yang bertujuan membentuk dan membina warga negara yang baik, yaitu warga negara yang tahu, mau, dan mampu berbuat baik. Untuk mencapai tujuan ini sebagai hasil yang dicapai melalui pembelajaran, memang tidaklah mudah. Guru harus mampu menciptakan kondisi pembelajaran yang kondusif, menggairahkan, serta mampu menjalin ikatan emosi antara dirinya sebagai fasilitator dengan siswa. Menurut Sudjana dan Suwariyah (1991:23) ada beberapa kondisi dan persyaratan yang harus diciptakan guru dalam kegiatan pembelajaran. Kondisi dan persyaratan tersebut berkenaan dengan aspek-aspek psikologis anak, lingkungan dan suasana belajar, bantuan atau bimbingan belajar dari guru, dan bentuk-bentuk belajar.

Keempat kondisi dan persyaratan di atas harus disiapkan dan diciptakan dengan baik. Guru harus mampu menerapkan model pembelajaran dan keterampilan khusus di samping secara benar memahami karakteristik siswa dan cara belajarnya. Model pembelajaran yang menciptakan kondisi pembelajaran sebagai mana disebutkan di atas harus dipilih dengan tepat.

Salah satu faktor yang sangat mendukung keberhasilan guru dalam mengelola pembelajaran adalah kemampuan guru dalam mengelola pembelajaran salah satu diantaranya kemampuan guru dalam menguasai dan menerapkan model pembelajaran di kelas. Guru dituntut untuk menguasai berbagai macam pembelajaran yang sesuai dengan karakteristik materi dan siswa, sehingga dalam penggunaan model pembelajaran tidak harus sama untuk semua pokok bahasan, sebab dapat saja terjadi bahwa suatu model pembelajaran tertentu cocok untuk satu pokok bahasan tetapi tidak cocok untuk pokok bahasan yang lain (Soemantri, 2007: 25)

Kondisi riil yang ditemukan pada siswa kelas V SD Negeri 1 Nelombu, pembelajaran PKn masih diajarkan dengan menggunakan metode ceramah yang menyebabkan motivasi belajar siswa kurang sehingga hasil belajar PKn siswa rendah. Hasil ulangan semester ganjil tahun 2015/2016 menunjukkan bahwa dari 20 orang siswa kelas V SD Negeri 1 Nelombu, hanya 8 siswa memperoleh nilai $\geq 70$ dan 15 orang siswa memperoleh nilai $<70$. Berdasarkan hal tersebut maka peneliti melakukan penelitian tindakan kelas dengan judul "Meningkatkan Hasil Belajar PKn Materi Menjaga Keutuhan NKRI Melalui Penerapan Model Pembelajaran Kooperatif Tipe Number Head Together (NHT) pada Siswa Kelas V SD Negeri 1 Nelombu Kabupaten Kolaka".

Terdapat beberapa penelitian yang relevan dengan penelitian yang dimaksud yaitu penelitian yang dilakukan oleh: Indriani (2010) dengan judul Meningkatkan Hasil Belajar PKn pada Materi Berorganisasi Melalui Pembelajaran Kooperatif Tipe NHT (Number Head Together) pada Siswa Kelas V SDN 02 Mandonga Kecamatan Mandonga Kota Kendari. Pada siklus I persentase ketuntasan hasil belajar siswa sebesar 55\% dan pada siklus II sebesar 85\%. Kesimpulan dari penelitian ini adalah penerapan model pembelajaran kooperatif tipe NHT dapat meningkatkan hasil belajar PKn siswa kelas V SD Negeri 02 Mandonga Kecamatan Mandonga Kota Kendari pada materi Berorganisasi dan Rahmawati (2011) dengan judul Keefektifan Model Pembelajaran Kooperatif Tipe NHT pada Pembelajaran PKn Materi Keputusan Bersama Siswa Kelas V SD Negeri 1 Angkasa Tahun Pelajaran 2010/2011. Pada siklus I ketuntasan hasil belajar siswa sebesar $60 \%$ dan pada siklus II persentase ketuntasan hasil belajar siswa meningkat menjadi $88 \%$. Kesimpulan dari penelitian ini adalah pembelajaran PKn dengan menggunakan model pembelajaran kooperatif tipe NHT lebih efektif daripada pembelajaran PKn dengan menggunakan metode ekspositori pada materi pokok Keputusan Bersama di kelas V SD Negeri 1 Angkasa tahun pelajaran 2008/2009. 
Masalah dalam penelitian ini adalah apakah aktivitas mengajar guru, aktivitas belajar siswa dan hasil belajar siswa pada materi Menjaga Keutuhan NKRI dapat ditingkatkan melalui penerapan Model Pembelajaran Kooperatif Tipe NHT di Kelas V SDN 1 Nelombu? Tujuan penelitian ini adalah untuk meningkatkan aktivitas mengajar guru, aktivitas belajar siswa dan hasil belajar siswa pada materi Menjaga Keutuhan NKRI melalui penerapan Model Pembelajaran Kooperatif Tipe NHT di Kelas V SDN 1 Nelombu Kabupaten Kolaka

\section{Metode Penelitian}

Jenis penelitian ini adalah penelitian tindakan kelas (PTK). Penelitian ini telah dilaksanakan pada semester I tahun pelajaran 2016/2017 bertempat di kelas V SD Negeri 1 Nelombu Kabupaten Kolaka. Penelitian ini disetting dalam dua siklus. Subjek penelitian ini adalah guru dan siswa kelas V SD Negeri 1 Nelombu Kabupaten Kolaka dengan umlah siswa sebanyak 16 orang, masing-masing terdiri dari 9 orang siswa perempuan dan 7 orang laki-laki. Faktor yang diteliti adalah guru, siswa dan hasil belajar. Menurut Wardani (2004:212) bahwa langkah dalam PTK merupakan satu daur atau siklus yang terdiri dari: (1) perencanaan (planning), (2) pelaksanaan tindakan (action), (3) observasi dan evaluasi (observation and evaluation), (4) refleksi (reflection). Data penelitian ini terdiri atas data primer dan data sekunder. Data primer yaitu data hasil belajar siswa pada materi pembelajaran PKn. Data sekunder yaitu data aktivitas guru dan siswa dalam proses pembelajaran PKn. berikut.

Data dalam penelitian ini dianalisis secara deskriptif dengan langkah-langkah sebagai

1. Menentukan ketuntasan belajar

a. Ketuntasan Individu

Ketuntasan individu siswa ditentukan berdasarkan nilai yang diperoleh pada setiap siklus. Siswa dikatakan belajar tutas jika nilai yang diperoleh siswa adalah $\geq 70$ sesuai Kriteria Ketuntasan Minimal (KKM) yang ditetapkan sekolah.

b. Ketuntasan Klasikal

Ketuntasan klasikal ditentukan berdasarkan persentase ketuntasan individu siswa pada setiap siklus pembelajaran dengan rumus sebagai berikut.

$$
\% \text { tuntas }=\frac{\sum f i}{n} \times 100 \% \quad(\text { Suparno, 2008: 82) }
$$

Dengan :

n : Jumlah siswa secara keseluruhan

$\sum f i$

: Jumlah siswa pada kategori ketuntasan belajar

Ketuntasan klasikal tercapai jika minimal $80 \%$ siswa telah mencapai ketuntasan individual.

2. Menentukan Keberhasilan Aktivitas Mengajar Guru

Untuk menentukan keberhasilan aktivitas mengajar guru dapat dilihat pada keterlaksanaan skenario pembelajaran. Persentase keterlaksanaan skenario pembelajaran dihitung berdasarkan jumlah skor perolehan guru dibagi dengan jumlah skor maksimum dikalikan dengan seratus persen.

$$
\% K A M G=\frac{J S P G}{J S M G} x 100 \% \quad \text { (Usman dan Setiawati, 1993: 139) }
$$

Dengan:

JSPG : Jumlah skor perolehan guru dalam pelaksanaan skenario pembelajaran

JSMG : Jumlah skor maksimum skenario pembelajaran

3. Menentukan Keberhasilan Aktivitas Belajar Siswa

Keberhasilan pembelajaran siswa dihitung berdasarkan skor perolehan siswa kemudian dibagi dengan jumlah skor maksimum dikalikan dengan seratus persen.

$$
\begin{aligned}
& \% K A B S=\frac{J S P S}{J S M S} x 100 \% \quad \text { (Usman dan Setiawati, 1993: 132) } \\
& \text { JSPS : Jumlah skor perolehan siswa dalam mengikuti proses pembelajaran } \\
& \text { JSMS : Jumlah skor maksimum proses pembelajaran }
\end{aligned}
$$


Indikator keberhasilan penelitian ini adalah ketuntasan belajar PKn siswa dan keberhasilan proses pembelajaran. Ketuntasan belajar siswa tercapai jika minimal $80 \%$ siswa memperoleh nilai $\geq 70$ sesuai KKM yang ditetapkan sekolah. Proses pembelajaran dikatakan berhasil jika persentase keberhasilan aktivitas mengajar guru dan persentase keberhasilan aktivitas belajar siswa mencapai $\geq 80 \%$.

\section{Hasil Penelitian}

Data yang diperoleh dari hasil penelitian ini adalah berupa aktivitas siswa selama kegiatan pembelajaran, aktivitas guru dalam pembelajaran, dan hasil evaluasi pada setiap siklus. Data-data tersebut dianalisis dengan menggunakan statistik deskriptif yang dimaksudkan untuk memberikan gambaran tentang aktivitas pembelajaran dan distribusi hasil belajar PKn pada materi Menjaga keutuhan NKRI dengan model pembelajaran kooperatif tipe NHT berupa rerata dan persentase ketuntasan belajar.

Sebelum melakukan tindakan penelitian, peneliti melakukan observasi dan wawancara dengan observer/teman sejawat untuk mengetahui hasil belajar siswa dan kelemahan-kelamahan dalam proses pembelajaran pada mata pelajaran PKn. Hasil observasi dan wawancara yang dilakukan menunjukkan bahwa hasil belajar PKn siswa Kelas V SD Negeri 1 Nelombu masih rendah.

\section{Hasil Observasi Aktivitas Guru}

Hal-hal yang diobservasi pada tindakan siklus I adalah cara guru menyajikan materi pelajaran apakah sudah sesuai dengan RPP atau belum. Kesesuaian aktivitas mengajar guru dengan RPP menjadi indikator keberhasilan aktivitas mengajar guru. Hasil observasi aktivitas mengajar guru siklus I menunjukkan bahwa skor perolehan guru pada siklus I pertemuan pertama adalah 11 dan pertemuan kedua adalah 13 sedangkan skor maksimum adalah 15. Keberhasilan aktivitas mengajar guru dihitung berdasarkan skor perolehan guru dibagi dengan skor maksimum dikalikan seratus persen maka persentase keberhasilan aktivitas mengajar guru siklus I pertemuan pertama adalah $73,33 \%$ dan pertemuan kedua $86,67 \%$. Jadi rata-rata persentase keberhasilan aktivitas mengajar guru sikls I adalah $80 \%$. Berdasarkan observasi pembelajaran siklus II diperoleh skor aktivitas guru. Skor perolehan guru pada siklus II pertemuan pertama adalah 14 dan pertemuan kedua adalah 15 maka persentase keberhasilan aktivitas mengajar guru siklus II pertemuan pertama adalah 93,33\% dan pertemuan kedua $100 \%$. Jadi rata-rata persentase keberhasilan aktivitas mengajar guru siklus II adalah $96,67 \%$.

\section{Observasi Aktivitas Siswa}

Pada tindakan siklus I, siswa kurang antusias mengikuti proses pembelajaran. Aktivitas siswa dalam kelompok belajarnya belum maksimal dan siswa pasif hanya pasif dalam proses diskusi kelompok dan diskusi kelas. Hasil observasi aktivitas siswa menunjukkan bahwa aktivitas siswa pada proses pembelajaran masih rendah. Skor perolehan siswa pada siklus I pertemuan pertama adalah 11 dan pertemuan kedua adalah 13 sedangkan skor maksimum adalah 15 maka persentase keberhasilan aktivitas belajar siswa siklus I pertemuan pertama adalah 73,33\% dan pertemuan kedua $86,67 \%$. Jadi rata-rata persentase keberhasilan aktivitas belajar siswa siklus I adalah $80 \%$. Pada pembelajaran siklus II keberhasilan aktivitas siswa dalam kegiatan pembelajaran meningkat. Skor perolehan siswa pada tindakan pembelajaran siklus II pertemuan pertama adalah 14 dan pertemuan kedua adalah 15 sedangkan skor maksimum adalah 15 maka persentase keberhasilan aktivitas belajar siswa siklus II pertemuan pertama adalah 93,33\% dan pertemuan kedua $100 \%$. Jadi rata-rata persentase keberhasilan aktivitas belajar siswa siklus I adalah 96,67\%.

\section{Hasil Belajar Siswa}

Setelah melaksanakan tindakan pembelajaran dua kali pertemuan, guru mengadakan evaluasi untuk menentukan ketuntasan belajar siswa. Hasil analisis ketuntasan belajar siswa pada siklus I dapat dilihat pada tabel berikut: 
Tabel 1. Analisis Ketuntasan Belajar Siswa Siklus I

\begin{tabular}{cccc}
\hline Skor & Jumlah Siswa & $\begin{array}{c}\text { Persentase } \\
(\mathbf{\%})\end{array}$ & Ketuntasan Belajar \\
\hline $0-69$ & 5 & 31,2 & Belum Tuntas \\
\hline $70-100$ & 11 & 68,8 & Tuntas \\
\hline Jumlah & $\mathbf{1 6}$ & $\mathbf{1 0 0}$ & \\
\hline Skor Rata-Rata & $: 67,14$ & & \\
\hline Persentase & $: 68,8$ & & \\
\hline
\end{tabular}

Sumber : Diolah dari data penelitian

Tabel di atas menunjukkan bahwa pada pembelajaran siklus I, siswa yang memperoleh skor antara 0-69 berjumlah 5 Siswa (31,2\%), siswa yang memperoleh skor rentang 70-100 berjumlah 11 Siswa $(68,8 \%)$. Ketuntasan belajar siswa pada siklus I mencapai $68,8 \%$ sedangkan siswa yang belum mencapai ketuntasan belajar adalah $31,2 \%$.

Setelah pelaksanaan tindakan siklus II selama dua kali pertemuan, diadakan evaluasi dengan tes. Dari hasil tes siklus II kemudian dianalisis untuk menentukan ketuntasan belajar siswa. Hasil anlisis ketuntasan belajar siswa pada siklus II selengkapnya dapat dilihat pada tabel berikut:

Tabel 2. Analisis Ketuntasan Belajar Siswa pada Evaluasi Siklus II

\begin{tabular}{cccc}
\hline Skor & Jumlah Siswa & $\begin{array}{c}\text { Persentase } \\
(\mathbf{\%})\end{array}$ & Ketuntasan Belajar \\
\hline $0-69$ & 1 & 6,2 & Belum Tuntas \\
\hline $70-100$ & 15 & 93,8 & Tuntas \\
\hline Jumlah & $\mathbf{1 6}$ & $\mathbf{1 0 0}$ & \\
\hline Skor Rata-Rata & $: 77,86$ & & \\
\hline Persentase & $: 93,8 \%$ & & \\
Sumber : Diolah dari data penelitian & &
\end{tabular}

Tabel di atas menunjukkan bahwa pada pembelajaran siklus II, siswa yang memperoleh skor antara 0-69 adalah 1 orang $(6,2 \%)$, siswa yang memperoleh skor rentang 70-100 berjumlah 15 orang $(93,8 \%)$. Ketuntasan belajar siswa pada siklus II mencapai 93,8\% sedangkan siswa yang belum mencapai ketuntasan belajar adalah $6,2 \%$. Hasil ini sudah lebih baik jika dibandingkan dengan skor perolehan siswa pada evaluasi siklus I ini berarti bahwa indikator keberhasilan penelitian sudah tercapai.

\section{Pembahasan}

Hasil belajar siswa ditentukan oleh dua faktor yaitu intern dan ekstren. Faktor intern meliputi pengetahuan yang sudah dimiliki oleh siswa sebelum mengikuti pelajaran berikutnya, keterampilan belajar yang dimiliki oleh siswa, mengerjakan tugas, membaca buku, belajar kelompok, kondisi pribadi siswa yang meliputi kesehatan, kecerdasan, sikap, cita-cita. Faktor ekstern meliputi proses belajar mengajar, sarana belajar yang dimiliki, lingkungan belajar, dan kondisi sosial ekonomi keluarga.

Untuk mengukur tingkat keberhasilan perbaikan pembelajaran yang dilakukan, maka guru mengadakan evaluasi pada setiap siklus pembelajaran. Pada evaluasi siklus I, siswa yang memperoleh skor $\geq 70$ sebanyak 11 Siswa $(68,8 \%)$, sedangkan siswa yang memperoleh skor $<70$ sebanyak 5 Siswa $(31,2 \%)$. Ketuntasan belajar siswa pada siklus I sudah meningkat yang mencapai $68,8 \%$ akan tetapi belum mencapai indikator keberhasilan penelitian yakni minimal $80 \%$ mencapai ketuntasan belajar. Ketidaktuntasan dari beberapa siswa tersebut diakibatkan kurangnya perhatian siswa pada saat mengikuti pelajaran dan kurang aktif mengerjakan LKS dalam kelompok.

Berdasarkan hasil evaluasi yang dilakukan pada siklus II, siswa yang memperoleh skor $\geq 70$ sebanyak 15 orang $(93,8 \%)$ dengan rata-rata skor perolehan siswa adalah 77,86. Ini menunjukkan bahwa terjadi peningkatan persentase ketuntasan belajar siswa antara siklus I dan siklus II. Indikator keberhasilan dalam penelitian ini telah tercapai yakni minimal 80\% siswa telah 
mencapai ketuntasan belajar atau mendapat skor $\geq 70$, tingginya hasil belajar siswa melalui model pembelajaran kooperatif tipe NHT disebabkan karena siswa belajar secara bersama dan saling membantu antara yang siswa yang mampu dengan siswa yang kurang mampu. Dalam pembelajaran kooperatif tipe NHT, siswa bertanya dan mengemukakan pendapatnya dalam proses diskusi kelompok dan diskusi kelas. Sesuatu yang dipelajari apabila siswa aktif mencari, memproses dan mengelola perolahan belajarnya sendiri serta bekerja sama dengan temannya akan lebih lama diingat dibandingkan dengan belajar yang hanya sekedar diperolehnya langsung dari guru dengan melalui ceramah atau informasi semata dari pendidik. Adanya peningkatan aktivitas siswa yang signifikan dari siklus I sampai siklus II karena siswa sudah mampu bersosialisasi dengan baik bahkan sebagian besar siswa sudah dapat mengeluarkan pendapatnya dan menjawab pertanyaan yang diberikan.

Penelitian tindakan kelas ini dilaksanakan dalam 2 (dua) siklus. Setiap siklus dilakukan tindakan pembelajaran dalam dua kali pertemuan. Tindakan pembelajaran dilaksanakan sesuai skenario pembelajaran dengan menerapkan model pembelajaran kooperatif tipe NHT. Berdasarkan hasil refleksi terhadap aktivitas guru pada siklus I menunjukkan bahwa penerapan model pembelajaran kooperatif tipe NHT belum sempurna. Pada pembelajaran siklus I pertemuan pertama dan pertemuan kedua, masih terdapat kekurangan-kekurangan yang harus diperbaiki. Hal tersebut terlihat dari hasil observasi yang dilakukan observer terhadap guru (peneliti) yang menunjukkan bahwa skenario pembelajaran belum sepenuhnya terlaksana. Penyampaian materi pembelajaran kurang runtut dan sistematis. Siswa tidak termotivasi untuk mengikuti pelajaran sehingga kurang menumbuhkan keceriaan dan antusias siswa dalam belajar.

Pada pembelajaran siklus II, guru dan siswa telah melakukan kegiatan pembelajaran sesuai yang diharapkan, dimana kekurangan-kekurangan yang terjadi pada siklus I sudah diperbaiki. Peneliti sudah mampu mengorganisasikan waktu pembelajaran dengan baik sehingga penggunaan waktu sudah sesuai dengan yang telah ditetapkan. Pernyataan ini sejalan dengan Sanjaya (2008: 27), untuk merencanakan pembelajaran, alokasi waktu yang diperlukan untuk mempelajari satu materi pelajaran perlu ditentukan. Penentuan alokasi waktu sangat bergantung pada keleluasaan materi serta tingkat kepentingan dengan keadaan dan kebutuhan setempat. Selain itu, guru sudah mampu menumbuhkan keceriaan dan antusias siswa dalam belajar, dan siswa sudah terlihat aktif dalam mengikuti kegiatan pembelajaran.

Hasil Perbaikan aktivitas pembelajaran siklus I berdampak pada peningkatan keberhasilan aktivitas mengajar guru dan aktivitas belajar siswa siklus II. Persentase keberhasilan aktivitas mengajar guru siklus I pertemuan pertama adalah 73,33\% dan pertemuan kedua 86,67\% dengan rata-rata persentase keberhasilan adalah $80 \%$ dapat ditingkatkan pada siklus II menjadi $93,33 \%$ pada pertemuan pertama dan $100 \%$ pada pertemuan kedua dengan rata-rata persentase keberhasilan $96,67 \%$.

Belajar adalah suatu proses perubahan tingkah laku pada diri individu berkat adanya interaksi antara individu dan individu dengan lingkungannya (Usman, 1995:5). Belajar sebagai suatu proses, ditandai dengan adanya perubahan pada diri seseorang. Winkel (1986:36) menyatakan bahwa belajar adalah suatu aktivitas mental/psikis, yang berlangsung dalam interaksi aktif dengan lingkungannya, yang menghasilkan perubahan-perubahan dalam pengetahuan, pemahaman, keterampilan dan skor sikap. Perubahan itu bersikap secara relatif, konstan dan berbekas.

Aktivitas siswa pada pelaksanaan pembelajaran materi pokok Menjaga keutuhan NKRI dengan model pembelajaran kooperatif tipe NHT, pada siklus I menunjukkan bahwa skor perolehan siswa masih rendah. Siswa belum mempunyai keberanian untuk menjawab pertanyaan yang diajukan guru. Hal ini disebabkan kurangnya rasa kepercayaan diri siswa untuk mengemukakan pendapat. Untuk meningkatkan aktivitas dan hasil belajar, maka hasil refleksi pada siklus I dijadikan dasar peneliti untuk melakukan perbaikan pada siklus II. Melalui perbaikan tersebut, aktivitas siswa pada siklus II sudah mengalami peningkatan terutama keberanian menjawab pertanyaan yang diajukan guru dan siswa sudah dapat mengikuti langkah-langkah pembelajaran kooperatif tipe NHT. 
Dengan model pembelajaran kooperatif tipe NHT seperti ini, proses tanya jawab dilakukan dengan cara guru menunjuk siswa secara acak sehingga setiap siswa mau tidak mau harus berpartisipasi aktif, siswa tidak bisa menghindar dari proses pembelajaran, setiap saat siswa bisa dilibatkan dalam proses tanya jawab. Kemungkinan akan terjadi suasana tegang, namun demikian proses interaksi antara guru dan siswa bisa dibiasakan. Untuk mengurangi kondisis tegang tersebut, guru hendaknya membuat serangkaian pertanyaan disertai dengan wajah ramah, suasana menyejukkan, nada lembut.

Hasil Perbaikan aktivitas pembelajaran siklus I berdampak pada peningkatan keberhasilan aktivitas belajar siswa siklus II. Persentase keberhasilan aktivitas belajar siswa siklus I pertemuan pertama adalah $73,33 \%$ dan pertemuan kedua $86,67 \%$ dengan rata-rata persentase keberhasilan adalah $80 \%$, meningkat menjadi $93,33 \%$ pada pertemuan pertama dan $100 \%$ pada pertemuan kedua dengan rata-rata persentase keberhasilan $96,67 \%$ pada siklus II.

\section{Simpulan}

1. Penerapan model pembelajaran kooperatif tipe NHT dapat meningkatkan aktivitas mengajar guru kelas V SD Negeri 1 Nelombu. Hal ini dapat dilihat dari persentase keberhasilan aktvitas mengahjar guru. Pada siklus I persentase keberhasilan aktivitas mengajar guru pertemuan pertama adalah $73,33 \%$ dan pertemuan kedua $86,67 \%$ dengan rata-rata persentase keberhasilan 80\%. Pada siklus II persentase keberhasilan aktivitas mengajar guru pertemuan pertama meningkat menjadi $93,33 \%$ dan pertemuan kedua $100 \%$ dengan rata-rata persentase keberhasilan $96,67 \%$.

2. Penerapan model pembelajaran kooperatif tipe NHT dapat meningkatkan aktivitas belajar siswa kelas V SD Negeri 1 Nelombu. Hal Ini dapat dilihat dari peningkatan persentase keberhasilan aktivitas belajar siswa. Persentase keberhasilan aktivitas belajar siswa siklus I pertemuan pertama adalah $73,33 \%$ dan pertemuan kedua $86,67 \%$ dengan rata-rata persentase keberhasilan $80 \%$ meningkat menjadi $93,33 \%$ pada pertemuan pertama dan $100 \%$ pada pertemuan kedua dengan rata persentase keberhasilan $96,67 \%$ pada siklus II.

3. Penerapan model pembelajaran kooperatif tipe NHT dapat meningkatkan hasil belajar siswa pada mata pelajaran PKn materi menjaga keutuhan NKRI di kelas V SD Negeri 1 Nelombu. Hal ini dapat dilihat pada peningkatan hasil belajar siswa, pada siklus I rata-rata hasil belajar siswa adalah 67,14 dengan persentase ketuntasan hasil belajar sebesar 68,8\% sedangkan pada siklus II rata-rata nilai hasil belajar siswa menjadi 77,86 dengan ketuntasan hasil belajar sebesar $93,8 \%$.

\section{Daftar Pustaka}

Indriani, 2010. Meningkatkan Hasil Belajar PKn pada Materi Berorganisasi Melalui Pembelajaran Kooperatif Tipe NHT (Number Head Together) pada Siswa Kelas V SDN 02 Mandonga Kecamatan Mandonga Kota Kendari Skripsi. UHO. Kendari.

Rahmawati, 2011. Keefektifan Model Pembelajaran Kooperatif Tipe NHT pada Pembelajaran PKn Materi Keputusan Bersama Siswa Kelas V SD Negeri 1 Angkasa Tahun Pelajaran 2010/2011. Skripsi. UT. Kendari.

Sanjaya Wina. 2008. Perencanaan dan Desain Sistem Pembelajaran. Jakarta: Kencana.

Soemantri, Numan. 2007. Pembaharuan Pendidikan Kewarganegaraan. Bandung: Rosda Karya.

Sudjana dan Suwariya. 1991. Model-Model Mengajar CBSA. Bandung: Sinar Baru.

Suparno, Paul. 2008. Riset Tindakan untuk Pendidik. Jakarta: Grasindo 
Jurnal Ilmiah Pembelajaran Sekolah Dasar

Volume 1 Nomor 2 - Agustus 2019,e-ISSN 26560402

Available online at:http://ojs.uho.ac.id/index.php/jipsd

Usman Uzer dan Setiawati Lilis. 1993. Upaya Optimalisasi Kegiatan Belajar Mengajar. Remaja Rosdakarya. Bandung.

Usman, U. 1995. Menjadi Guru Profesional. Bandung: Remaja Rosdakarya

Winkel, W.S. 1986. Psikologi Pengajaran. Jakarta: Gramedia Widiasarana Indonesia. 